

\section{Shirkah}

\section{Journal of Economics and Business \\ Vol. 1, No. 1, January-April 2016 \\ ISSN: 2503-4235 (p); 2503-4243 (e)}

\section{Editor in Chief}

Sri Walyoto

\section{Editorial Boards}

Ahmad Ihwan Setiawan, Faculty of Economics, Universitas Sebelas Maret

Dwi Condro Triono, Faculty of Islamic Economics and Business, IAIN

Surakarta

Fahmy Radhi, Faculty of Economics, Universitas Gadjah Mada

Jaka Sriyana, Faculty of Economics, Universitas Islam Indonesia

\section{Managing Editors}

M. Endy Saputro

M. Zainal Anwar

\section{Assistant to Editor}

Supriyanto

Shirkah Journal of Economics and Business is a peer-reviewed journal published three times a year (January-April, May-August and September-December) by Faculty of Islamic Economics and Business, Institut Agama Islam Negeri (IAIN/ State Institute for Islamic Studies) Surakarta Central Java, Indonesia. The main objective of Shirkah is to offer an academic space of exchange ideas and initiate the increase number of qualified article produced by postgraduate students, practitioners and academicians.

\section{Editorial Office}

Ruang Jurnal Shirkah

Lantai Dasar, Sayap Barat, Fakultas Ekonomi dan Bisnis Islam, IAIN Surakarta

Jln. Pandawa No. 1, Kartasura, Sukoharjo, Jawa Tengah Kode Pos. 57168

Phone (+62271) 781516 Fax: (+62271)782336

E-mail: shirkahiainsurakarta@gmail.com

Website: http://shirkah.or.id/ 


\section{Shirkah}

Journal of Economics and Business

Vol. 1, No. 1, January-April 2016

ISSN: 2503-4235 (p); 2503-4243 (e)

\section{Table of Contents}

\section{Articles}

Muthmainah

The Growth of Sharia Insurance in Indonesia 2015 - 2016

An Academic Forecast Analysis

Meilana Widyaningsih

$23-46$

The Effect of Material, Social and Activities Compensations

toward Work Performance Using Organizational Commitment

as The Mediator

Tri Wabyuni

$47-72$

The Influence of Technology Acceptance Model (TAM)

on The Users' Behavior of Sikesya Application in IAIN Surakarta

M. Nidaussalam

Mudaraba as a Model of Islamic Finance

Sri Maryati

$93-112$

Evaluating The Performance of Inventory Management

The Production Division of PT. Tiga Serangkai Surakarta

as a Case Study

Mardhiyaturrositaningsih

$113-126$

Sharia Banking's Profit Loss Finance in the Context of ASEAN Economic Community 


\title{
Sharia Banking's Profit Loss Finance in the Context of ASEAN Economic Community
}

\author{
Mardhiyaturrositaningsih \\ Islamic Law, Graduate Program, \\ State Islamic University (UIN) Yogyakarta
}

\begin{abstract}
The paper's aim is analyzing the problems of profit and loss sharing financing. It was conducted with literature and interviews on funding customers, Islamic bankers and entrepreneurs. The results show that profit oriented lack of trust in the abilities of partners, moral hazard, mismanagement and lack of sharia product information. In dong so, giving incentive for funding customers, incentive compatible constraint, involved effort in spiritual and intellectual expected may help small and medium enterprises to face ASEAN Economic Community.
\end{abstract}

\section{Keywords}

ASEAN Economic Community, profit and loss sharing financing, small and medium enterprises

ASEAN economic community is a sharing community of Southeast Asia countries in creating economic acceleration. This agreement has created a trading access which threats a country's stabilization economic condition. It will be a new challenge for the countries especially the ones in Southeast Asia to maximize their potential, Indonesia included. Indonesia is a potential market due to its largest population than any countries in Southeast Asia. Economic growth is a country success benchmarks which is slowing down for these last four years. Base on the Badan Pusat Statistik at the $3^{\text {rd }}$ quarter of 2015 Indonesia economic growth is at $4.73 \%$. This 
number shows the deceleration compares to the same period in 2014 .

Business sector role is needed to enhance Indonesia economic growth. Processing industry is the main contributor of Indonesia economic growth and it shows deceleration of second quarter 2015 at $20.87 \%$ to $20.41 \%$ at the third quarter 2015 . This deceleration affects the $4 \%$ exports value deceleration. Base on Badan Pusat Statistik data, Indonesia exports value is decreasing at January - October 2015 period. It is dominated by processing industry with $70.89 \%$. The data show business sector has important role in Indonesia economic growth.

Sharia banking is expected to have a role in supporting economic growth with contribution to businessperson. Mudharaba and musharaka profit loss sharing's financing is a financing type applied by sharia bank. This financing is more focusing in establishing real sector business productivity than consumptive need fulfillment. However, this finance is at minority part. Murabaha financing with trading principle is still dominating financing structure to this days with 59\% distribution.

The balance of liquidity and profitability is the main topic in bank activities as intermediary institution. Profit loss sharing with the involvement of depositor, bank, and businessperson is considered high risk. Business creates trade off on profit for the shareholder at one side and responsible of the stakeholder at the other side. Profit loss financing products which is more excellence than other financing type is marginalized due to risk's threat. The identified problems are the low profit loss financing, related parties' expectation, and the offered solution which will be focus of this paper.

\section{Profit Loss Sharing Financing}

Sharia bank as an intermediary institution has several products; profit loss sharing principle financing is one of them. This financing 
principle is in accordance in supporting real sector due to its ability to terminate the possibility of funding distribution for consumptive needs. It is a connector of skillful party and funding party enabling them creating productive business. This financing principle consists of financing with mudharaba and musharaka contract.

Mudharaba is a partnership contract of first party (shahibul maal) provides all modal (100\%) and other party as the manager. The profit is divided according to agreement. The loss is borne by the modal owner for not the mistake of the manager. The loss due to manager's mistake is the responsibility of the manager. Musharaka is partnership contract with each party contributes fund and work with the agreement of profit and risk sharing (Antonio, 2001, p. 90)

Profit and loss are two inseprable things in business activities. According to Muhammad (2014), Islam acknowledges al-Kharaj bi alDhaman or al Ghunmu bil Ghurmi method. The method said that a person has to bear the risk in gaining profit of her investment. The profit has to be gained with sharing risk and compensation of the ownership. Profit loss sharing financing is considered high risk. The trade off between risk and profit is becoming difficult to predict therefore bank is changing into financing with profit assurance.

Profit loss financing in fact provides higher profit. Bank will gain higher profit with this financing due to the profit affected by the customer business income. The higher the customer business income will make higher bank's profit and the other way around. The businessperson is also helped due to freedom of certain amount payment. Therefore, profit loss sharing financing distribution is relatively small. Trading principle financing, especially murabaha is still dominating distributed financing products with 59\%. The principle financing will give bank fixed profit. Therefore the financing customer should repay with fixed amount without 
consideration the amount of the business profit.

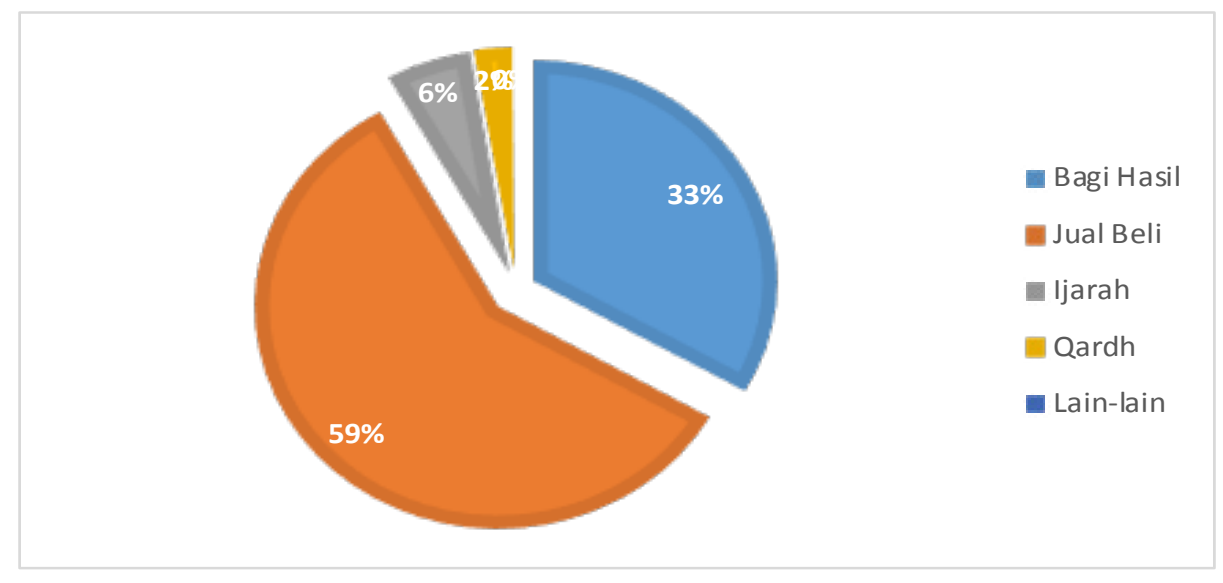

Sharia Bank Distributed Financing Composition

Source: Sharia Bank Statistic

Profit loss financing is involving depositor customer as fund owner and bank as mediator and businessperson. The balance of expectation and challenge of each party is needed due to the high amount of profit loss sharing financing potential in helping business activities. Asymmetric information according to several literature is considered as the main factor which affects the low profit loss sharing. Asymmetric information is a condition which shows some investors with information and the others without information (Muhammad, 2014, p. 476).

According to Muhammad (2014), asymmetric information format is usually in moral hazard and adverse selection. The effort to minimize this risk in literature is named incentive compatible constrains. This method provides several restrictions for businessperson. They are larger modal or guarantee, business condition with low risk, cash distribution transparancy and overhead expense cut. Shariah bank is expected to be able to minimize expense connection with asymmetric information with 
screening and monitoring activities (Muda, 2011, p. 3).

Ascarya (2011) divides the cause of low profit loss sharing financing into two factors, namely internal and external factor. Internal factor is realted to human resurce low quality and quantity, IT technical problem and SOP, and top management low commitment. The external factor is the low incentive and government regulation's support; and also society perception and trust. Muhammad Hanif (2010) does research on musharaka financing main obstraction factors in Pakistan are conventional bank, risk, profit manipulation, the lack of partner skill and trust, weak audit, conventional accountancy framework, and high tax. Khalil Rickwood and Murinde in Muhammad (2014) mentioned several bank consideration factors, namely busnessperson reputation; businessperson experience and qualification; Islamic teaching obediency, project profitability, financial record, financial distribution position; project uncertainty level; social and envronmental condition; profit time horizon; and asset security.

\section{Small and Medium Business}

Base on Law No. 20, 2008, small business is a business with net worth of 50 millions to 500 millions excluding the land and business building, or has annual selling of 300 millions to 2.5 billions. Median business is a business with worth more than 500 millions to 10 billions excluding land and the business building, or with annual selling more than 10 billions to 50 billions.

Small and median business (UKM) in Indonesia have several benefits therefore the governement is trying hard to develop this sector. The benefits are supporting economic growth; enhancing productivity; creating new technology, product, and service; creating market changes and competition; creating jobs; enhancing live quality; income distribution; sources mobilization and ustilization to enhance national productivity; 
and enhancing government prosperity with tax (Echdar, 2013, p. 23). The goals achievement has several obstractions. According to Nazaruddin (2014), the obstractions are low human resource quality; and also weak modal structure and market access. Small and median businesses have difficulties in accessing sharia bank modal due to small and median businesses high risk.

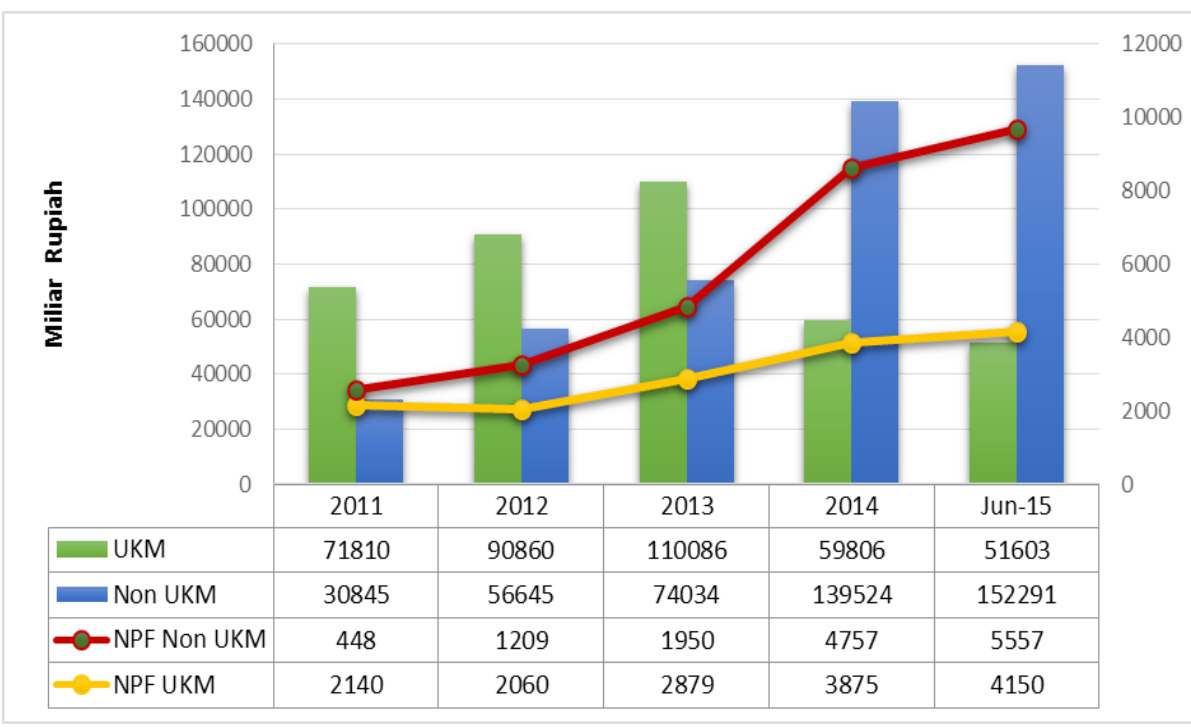

BUS and UUS Financing Based on Financing Type

Source: Sharia Bank Statistic

The data in this paper is gained of literature study with collecting reference books, journal, and interviews. The interviews are on direct and non-direct related to profit loss sharing financing distribution parties. The parties are bank management which consists of account officer and realtion officer; depositor customer who owns mudharabah saving; and businessperson. The field result will compare to the reference litertaures. The purpose is finding low profit loss sharing financing cause's identifications 
and expectation.

Sharia bank's profit loss sharing financing is involving three parties, namely sharia bank as intermediary institution, depository customer as modal owner, and businessperson as financing customer. Low profit loss sharing financing is affected by many factors. These factors identification is needed to create a strategy in the future. Therefore, expectation which is a desire to be achieved in a business activity needs to be attended.

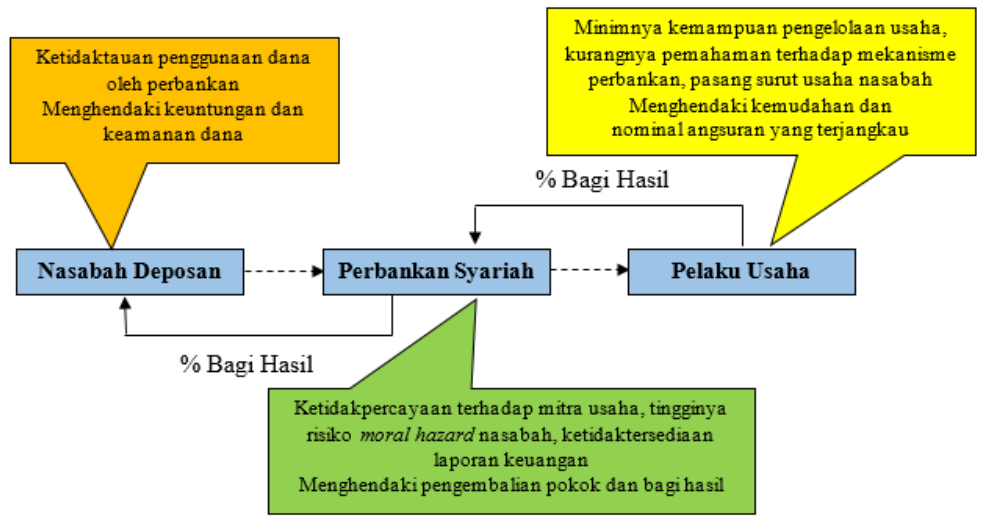

Identifying the Problems

Vol. 1 No. 1, January - April 2016 


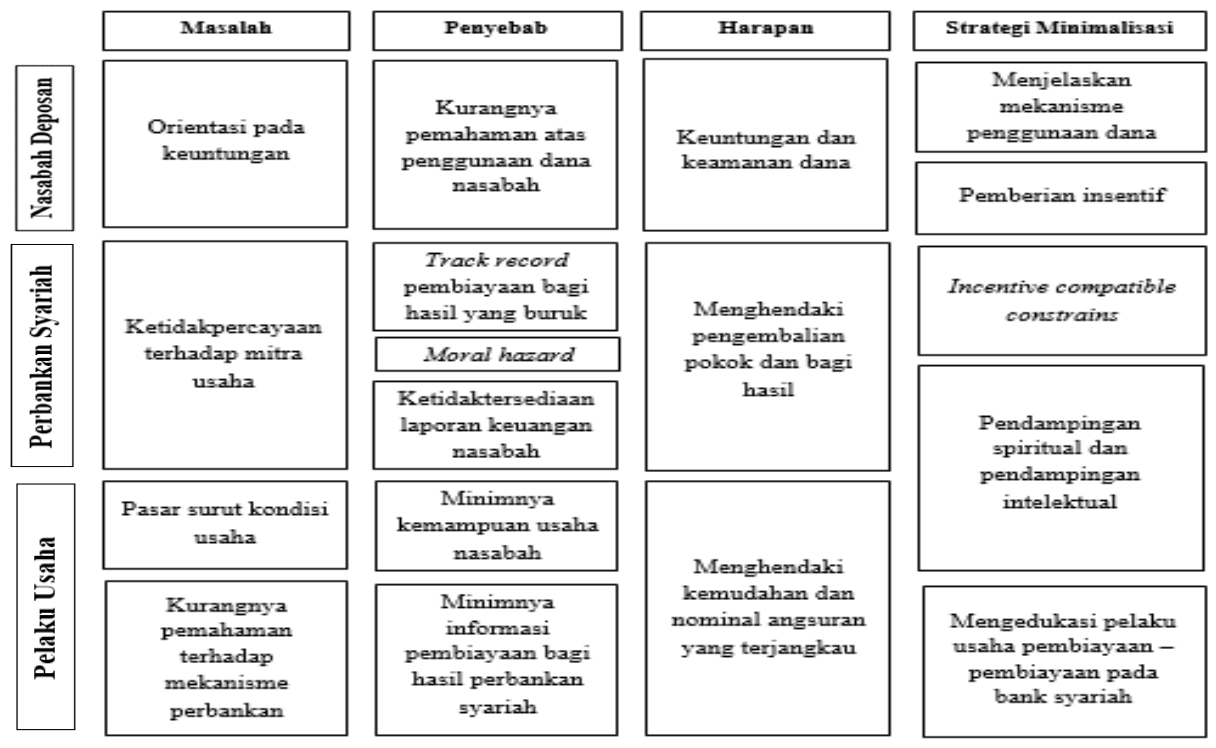

Low Profit Loss Sharing Financing and Minimizing Strategy

The problem identifications of low profit loss sharing financing and its solving strategies in risk minimizing are some folds. Depositor customers save their money in the bank expecting profit and safety. The depositor customers usually do not know where they money will be entrusted by the bank. Mudharaba contract will make customer meets profit and risk. Therefore, the information should be delivered to the customers to avoid undesirable things in the future.

The problem is depositors usually accentuate profit. Customers who save their money in the bank have not yet ready for pure profit loss sharing concept application. The customers actually still need a certain security level of their fund (Ascarya, 2011, p. 217). Depositor customers fund withdrawal is bank main consideration in distributing profit loss sharing financing principle, due on the high risk of this financing principle. Bank applies revenue sharing as strategy to minimize depositor fund 
withdrawal. This concept is determining profit loss sharing base on gross income before subtracted by bank operational expenses (Muhammad, 2011: 280). The expenses will be paid by the bank. Therefore bank is unwilling to use this high risk financing. Another effective method for the depositor customer and bank is initial intensive or certain nominal requirement financing as promotion.

Sharia bank as intermediary institution of excess-fund community and lack of fund community is facing tradeoff between the profit of profit loss sharing and social responsibility. It shows in the responsibility in financial distribution at profit loss sharing scheme and financing method which favors businessperson. The field research shows several things as a consideration for the bank to determine profit loss sharing. The problem is the banking sector distrust distrusts of its business partner. It is due to terrible track record financing, high risk moral hazard (dishonest customer), and unavailable customer's financial record. Moral hazard risk is the sharia bank main consideration in distributing profit loss sharing financing. The effort to minimize the risk in the literature is named incentive compatible constrains. It consists of larger modal portion policy or collateral enforcements; low risk business; and also cash distribution's transparency and overhead expenses cut.

Another method to minimize risk is business mentoring. It consists of two aspects namely spiritual and intellectual mentoring. Spiritual mentoring needs to be implanted in the fund manager customer. Religious foundation enhancement is the basic and self-control in avoiding deviant behavior (moral hazard) of the businessperson. The mechanism is proved to be effective in minimizing moral hazard high risk. Intellectual mentoring is also helping fund manager customer (businessperson) facing obstruction in the business. The mentoring will create partnership relation of customers and bank. Customer performance will be able to be closely 
monitored and make the expected profit. The mentoring is also helping the availability of financial report. Financial report unavailability is not intentional. This is because the customer does not have the knowledge make a financial report.

According to Sixpria (2014) the accountancy application in UMKM refers to SAK ETAP has not yet implicated due to UMKM businessperson's accountant limited knowledge to apply proper accountancy process. There is no financial report format which gives convenience for UMKM in providing business real time information. A simple financial report should consist of cash flow, active, obligation, modal, income, and expense. It will help the bank in monitoring and observing. One of businessperson's obstacles is unstable business condition. This condition is affected by customer limited ability to manage the business. It will be the bank's consideration in distributing modal contribution to business sector. Bank, in practice, requires guarantee and minimum 3 years operation in accessing bank modal. Small and median businessperson needs convenience in bank transaction.

Profit loss sharing does not need fixed repayment. It is in accordance with customer income from her/ his business, therefore it will help the small and median business. Many businesspersons do not know this financing scheme therefore the requirement of this financing principle is low. Society incomprehension on the sharia bank offered financing scheme and mechanism creates assumption the similarity of sharia and conventional bank. This assumption needs to be corrected. Bank need to provide education for businessperson to avoid this incorrect assumption. This education is urgent due to profit loss sharing financing potential in helping Indonesia economics with the role of small and median business.

Profit loss sharing financing will enable bank to participate in business. Business mentoring will help businessperson to survive in 
increasing intense competition. ASEAN economic community is the challenge for small and median business to survive in intense competition with other countries. Production quality enhancement with high competitiveness is needed immediately with modal contribution and business mentoring by sharia bank.

\section{Concluding Remarks}

Sharia bank active role with profit loss sharing financing has large potential in helping small and median business economic activities to deal with ASEAN Economic Community. Profit loss sharing financing is involving three parties, namely depositor customer as modal owner, sharia bank as intermediary institution, and businessperson. Problems and expectations of each party are needed to be attended.

Depositor customer is oriented on fund safety and profit. It is due to customer incomprehension on fund's utilization mechanism by the bank. The strategy to solve this problem is explanation of fund distribution mechanism and incentive providing which will be able to maintain old customers and gaining new ones. The bank's problem is distrust aspect which could be solved with incentive compatible constraint and business mentoring (spiritual and intellectual aspect). Businessperson's problems are related to customer business instability and lack of knowledge about shariah bank financing products which will be able to minimize with business mentoring and bank products education. The offered strategies are expected to support bank in distributing profit loss sharing financing principle for the small and median business. 


\section{References}

Antonio, Muhammad Syafi'i. (2001). Bank Syariah dari Teori ke Praktik. Jakarta: Gema Insani Press.

Ascarya. (2011). Akad dan Produk Bank Syariah. Jakarta, Raja Grafindo Persada.

Ascarya, The Lack of Profit and Loss Sharing Financing in Indonesia's Islamic Banks: Revisited

Saban, Echdar. (2013). Manajemen Entrepreneurship Kiat Sukses Menjadi Wirausaha. Yogyakarta: ANDI.

Hanif, Muhammad dan Abdullah Muhammad Iqbal, (2010). Islamic Financing and Business Framework: A Survey, European Journal of Social Science. 15 (4).

Muda, Ruhaini Binti dan Abdul Ghafar Ismail. (2011). Profit-Loss Sharing and Economic Value Added in Islamic Banking Model, Working Paper in Islamic Economic and Finance No. 1105, Research Center for Islamic Economics and Finance Universiti Kebangsaan Malaysia.

Muhammad (2005). Konstruksi Mudharabah dalam Bisnis Syariah. Yogyakarta: BPFE-Yogyakarta.

Muhammad. (2011). Manajemen Bank Syariah Edisi Revisi Kedua, Yogyakarta: UPP STIM YKPN

Muhammad. (2014). Manajemen Keuangan Syariah Analisis Figh dan Keuangan. Yogyakarta: UPP STIM YKPN.

Nazaruddin, Arif. (2014). Komunitas Ekonomi ASEAN: Seminar Keilmuan Nasional Perspektif Ekonomi Islam Menyongsong Perekonomian Indonesia Guna Menghadapi Pasar Bebas ASEAN 2015, 4 Februari 2014.

Otoritas Jasa Keuangan. (2015) Statistik Perbankan Syariah Juni 2015. Jakarta: Departemen Perizinan dan Informasi Perbankan Deputi Direktur Publikasi dan Administrasi Otoritas Jasa Keuangan. 
Sixpria, Nedsal et al. (2014). Implementasi Standar Akuntansi Entitas Tanpa Akuntabilitas Publik (SAK-ETAP) dalam Proses Akuntansi dan Penyusunan Laporan Keuangan Pada Usaha Mikro, Kecil dan Menengah (UMKM), Jurnal Akuntansi, Keuangan dan Perbankan.

\section{Document}

Badan Pusat Statistik, 2015, Perkembangan Ekspor dan Impor Indonesia Oktober 2015, Berita Resmi Statistik No. 104/11/Th. XVIII, (Jakarta: Badan Pusat Statistik).

Badan Pusat Statistik, 2015, Pertumbuhan Ekonomi Indonesia Triwulan III 2015 ,

Berita Resmi Statistik No. 101/11/Th. XVIII, (Jakarta: Badan Pusat Statistik). 
